\title{
State of drinking water and its management aspects in Dhaka city
}

\author{
SMG Yeazdani \\ Faculty of Arts and Social Sciences \\ Bangladesh University of Professional, Dhaka-1216, Bangladesh \\ (E-mail:dryeazdani@gmail.com)
}

\begin{abstract}
The population of Dhaka city is now assumed to be around 20 million. The city dwellers are facing acute shortage of water. Dhaka Water Supply and Sewerage Authority (DWASA) and Directorate of Public Health and Engineering (DPHE) are distributing water in Dhaka city. The present water demand is 2,474 MLD but the production is 2087.5. The DWASA is supplying water through 661 deep tube wells to the inhabitants of the city and more than 2000 private tube wells are abstracting water from different depths. This paper focuses on the demand and supply gap, collection pattern of water, its supply chain and wastages by different groups of people, finding alternative options to meet the crisis management etc. The DWASA needs to collect surface and rainwater and distribute after treatment. We recommend reducing the dependency on groundwater to maintain satisfactory underground level of water. The authority should replace the old supply chain by a new one, installing more number of new pumps with high capacity and establishing more number of overhead tanks. Industry and tannery should be relocated outsight the city to avoid water contamination and ensuring the availability of quality water. The Government should encourage the entrepreneurs by providing SME loan to establish more number of bottle/jar drinking water factories outskirts of Dhaka city and near the river bank under the close monitoring of Bangladesh Standard Testing Institute (BSTI), DWASA and DPHE to provide safe drinking water.
\end{abstract}

Keywords: Abstraction, depletion, demand, DWASA, supply, water resources.

Paper Received: 12 April 2015

Paper Accepted: 30 March 2016

\section{INTRODUCTION}

Water covers $71 \%$ of the earth's surface but, available fresh drinking water is only $3 \%$ out of which $69 \%$ is 'trapped' as ice in the two polar regions. The remaining fresh water are existing in rivers, lakes and surface aquifers which human beings, plants and other animal species can use. This distribution must be carefully managed to avoid irreversible depletion of the resource (WHO/UNICEF 2010). Water shortage in Dhaka is a key issue to achieve sustainable development. The 'Third World Water Forum' entitled water as a 'driving force for sustainable development'. In $6^{\text {th }}$ Governing Council Meeting of Asia Pacific Water Forum (APWF) it was said that the water demand of Dhaka city is 2470 MLD but the actual supply is 1930 MLD and water demand in the year 2030 will be 4,990 MLD. The potential groundwater recharge is only $1.33 \mathrm{~m} / \mathrm{yr}$ in contrast to $2.81 \mathrm{~m} / \mathrm{yr}$ of groundwater depletion rate (Uddin and Baten 2011). The water management is done by DWASA and DPHE which involves complicated and systematic processes. These government organizations are partially failing to provide safe drinking water to the people. Thus, a study has been carried out on "An Assessment of the State of Drinking Water and Its Management Aspects in Dhaka City". The study attempted to understand the trend and extent of demand for drinking water and its supply through analyzing the status of surface and groundwater reserve from the perspective of consumer demand. Simultaneously, quality of supplied water is also examined in this study to recommend possible steps to ensure the quality of supplied drinking water.

\section{SOURCES OF WATER}

Dhaka is surrounded by a number of rivers, lakes and canals. All the rivers, lakes and canals are interconnected with each other. The sources of water are; ground water, surface water, rain water, waste water and bottle/jar water.

\section{Groundwater resources}

Groundwater resources are determined by properties of groundwater storage reservoir and volume of annual recharge. Mainly rainfall, flooding and stream flow in rivers penetrate earth surface and finally recharge the groundwater reservoirs. Groundwater storage reservoirs are composed of three aquifers, these are upper aquifer or composite aquifer, main aquifer (it is at depths of $6 \mathrm{~m}$ in north-west and to $83 \mathrm{~m}$ in the south) and deep aquifer. In Bangladesh, the depth of water level varies from less than a meter to more than $30 \mathrm{~m}$. Some scientific studies on the groundwater of the city revealed that, the aquifer piezometric level which is the natural water level of a confined aquifer of the city main aquifer, has gone down significantly in last few years due to over withdrawal of groundwater (Akther et al. 2009). 


\section{Surface water resources}

Dhaka city is surrounded by numerous water resources. About $10-15 \%$ of Dhaka city's land areas are comprised of surface area including a number of rivers, canals and lakes. Major surface water bodies of Dhaka city are the Buriganga, Turag, Balu nadi, Tongi khal, Dhanmondi lake, Romna lake, Gulshan lake and Crescent lake etc. There are more than 35 canals which blocked Dhaka city area (Khan 2011) even though most of them are now fully encroached or polluted to a level that cannot be used even for washing purposes.

\section{Rainwater resources}

Rainwater is contributing a lot for supplying water from surface and ground sources. Harvesting rainwater for domestic purpose would allow city dwellers to a paradigm shift from present system. According to Meteorological Department, out of twelve months, only four months we have average approximately $60 \mathrm{~mm}$ rain in Dhaka city; remaining eight months we have average $370 \mathrm{~mm}$ rain. Nearly $80 \%$ of the annual average rainfall of 1,854 $\mathrm{mm}$ occurs during the monsoon season which lasts from May until the end of September (Fig. 1). The rain water sometimes pollutes the surface water in many ways. Recharge to deeper aquifers is more problematic to assess. Acid rain also pollutes the water. In order to harvest rainwater, it is urgent to know the procedures for installing the system, maintenance and corrective measures for it.

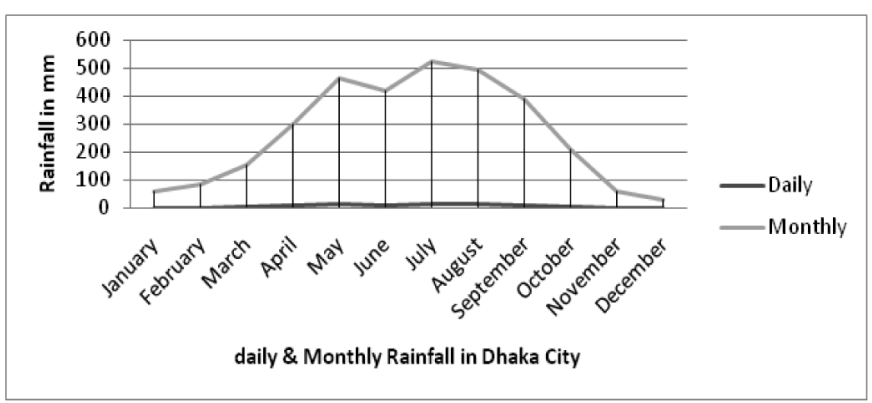

Fig. 1: Daily/monthly rainfall $(\mathrm{mm})$ in Dhaka city.

(Source: Bangladesh Meteorological Department)

\section{Waste and grey water}

Waste water includes substances like human waste, food scraps, oils, soap and chemicals; it also includes storm runoff and flood water. It may be mentioned that domestic household produce an average of 200-300 1 of waste water per person every day. Ninety nine percent of this waste water is water; the other one percent is the contaminating waste. As we are running shortage of water for that we should install waste water treatment plants. Studies reported that the amount of grey water produced in household is $55-65 \%$ of the total amount of waste water. Bangladesh Govenment may launch water reuse projects through public utility departments such as the Water Administration and Sewerage Authority (WASA), the City Corporations, the Department of Public Health Engineering (DPHE) etc.

\section{Bottled/Jar water}

Bottle water is becoming increasingly more popular day by day as another source of drinking water. Various big companies like partex, pran, ACI etc. including hundreds of small companies are supplying bottle water on the basis of consumer demand. DWASA also produce bottle water for its client. Around $62 \%$ people of Dhaka city have become used to with bottle and jar water as a source of drinking water. They wish to get the availability of jar water $(201)$ at a cost of $20 \mathrm{TK}$. Besides that, Bangladesh imports bottle from foregin countries.

\section{POLLUTION AND CONTAMINATION OF WATER}

Polluted water is not only dirty, it is deadly too. The problem is acute in the developing world. Lack of adequate sanitation contaminates water sources worldwide and is one of the most significant forms of water pollution. Worldwide, 2.5 billion people live without improved sanitation. Open defecation significantly compromises quality in nearby water bodies and poses an extreme human health risk. More than $80 \%$ of people in Bangladesh lack clean and safe water (Gomes 2005). Surface water pollution occurs in rivers, lakes, ponds and floodplains etc. Surface water in Dhaka city is extensively polluted by sources like industrial and urban wastes, agrochemicals and sewerage wastes and sea water intrusion. Therefore, the major causes of surface water pollution are; over population, unplanned sewerage system of DWASA, solid waste and others. Although groundwater is not directly exposed to surface polluting activities, numerous natural and anthropogenic activities cause groundwater pollution. Before the discovery of arsenic contamination in Bangladesh, groundwater used to be considered a safer source of drinking water. Arsenic contamination is geological and there is no known control at source and also there is no proven treatment for arsenicosis. Leaking sewers/septic tanks/pit latrines also cause ground water pollution. Contaminations are either man-made or naturally occurring. Some contaminants are organisms that include pathogens like bacteria, viruses, and parasites such as microscopic protozoa and worms. Drinking arsenic-rich water over a long period results in various health effects including skin diseases and problems (color changes on the skin, and hard patches on the palms and soles of the feet), diseases of the blood vessels of the legs and feet, and possibly also diabetes, high blood pressure and reproductive disorders.

\section{PRESENT STATE OF WATER}

Due to rapid urbanisation and migration from rural areas there is a tremendous load on water consumption in Dhaka city (Khan 2011). A major portion of the total water consumptions are; bathing, washing, flushing toilets and cleaning etc. In Dhaka city, groundwater extraction started from a depth of 100 $\mathrm{m}$ and in some extreme condition the well goes up to $300 \mathrm{~m}$ to reach the main aquifer. The depletion rate varies from area to area as in Mirpur the groundwater level dropped $53.75 \mathrm{~m}$ between 1991 and 2008 at a rate of $3.2 \mathrm{~m} / \mathrm{yr}$. While the decline was $1.1 \mathrm{~m} / \mathrm{yr}$ in Mohammadpur, $2.2 \mathrm{~m} / \mathrm{yr}$ in Sabujbagh, 0.5 
$\mathrm{m} / \mathrm{yr}$ in Sutrapur, and $0.8 \mathrm{~m} / \mathrm{yr}$ in Dhaka Cantonment during the same period. The city's groundwater level has dropped about $20 \mathrm{~m}$ over the last seven years at a rate of $2.81 \mathrm{~m} / \mathrm{yr}$, and from the year 2000, the rate is increasingly high. Taking into account the current groundwater depletion trend at $2.81 \mathrm{~m} / \mathrm{yr}$, a projection has been made which predicts that the groundwater table will be lowering down to $120 \mathrm{~m}$ by 2,050 from the existing water table. This depletion will hamper the constant water supply as many of the operating deep wells may shut down due to water scarcity. To get arsenic free drinking water, recharging of water must be maintained. The direct recharge of water from different rivers around Dhaka is contributing a portion to the aquifer but scope of vertical recharge is less due to dense urbanization. The Government should take necessary measures to stop the continuous reduction of wet land in Dhaka for maintaining satisfactory water level.

\section{MANAGEMENT AND STATE OF WATER SUPPLY}

The water supply in Dhaka city was first started with the establishment of Dhaka Water Works (DWW) by Nawab Sir Abdul Gani in 1874. Dhaka city dwellers were dependent on potable water for drinking and other purposes. Dhaka water supply and sewerage authority (DAWSA) was established in 1963 to construct, improve, expand, operate and maintain water supply and sewerage in Dhaka Metropolitan Area (DMA). DWASA has traditionally dealt with water supply and treatment as well as disposal of sewerage. The management is divided into a total of seven zones. DWASA is responsible to supply potable drinking water to the city dwellers but now they are facing difficulties in maintaining adequate level of drinking water supply. During the fiscal year 2010-2011, DWASA produced approximately 2,150 million liter of water per day of which $87 \%$ was extracted from underground level and only $13 \%$ water was sourced from two major rivers beside Dhaka. DWASA could not make any significant increase of water production. The present water production scenario is given below:

Table 1: Water production scenario of DWASA.

\begin{tabular}{|c|c|c|c|c|}
\hline \multirow{2}{*}{ Source } & \multirow{2}{*}{$\begin{array}{l}\text { Production } \\
\text { Capacity } \\
\text { (MLD) }\end{array}$} & \multicolumn{2}{|c|}{ Actual Production } & \multirow{2}{*}{$\begin{array}{c}\text { Source-wise \% } \\
\text { of Production }\end{array}$} \\
\hline & & MLD & $\begin{array}{c}\begin{array}{c}\% \text { of } \\
\text { capacity }\end{array} \\
\end{array}$ & \\
\hline Groundwater & 1948.3 & 1831.2 & 93.99 & 87.72 \\
\hline Surface water & 299.17 & 256.3 & 85.67 & 12.28 \\
\hline Total & 2247.47 & 2087.5 & 92.88 & 100 \\
\hline
\end{tabular}

(Source: DWASA 2014)

The DWASA has laid down 3,461.56 km water lines, given 329,615 water connections and they have installed four water treatment plants. The DWASA provides water through 661 deep tube-wells. The inhabitants of all the areas of Dhaka city hardly get equal supply of water by DWASA. As for instance, DWASA yet could not provide water meters to all the holdings. The present water demand is 2474 MLD, but the production is 2087.5 MLD (DWASA 2014). During field survey, it is found that the projected demand 2474 MLD is very insufficient. At present, 625 pumps are in operation. About 31.43 households in Dhaka city do not have access to the piped connections and they have to rely on standpipe connection or other sources to fulfill their minimum water demand. The public stands pipe connections are 1,727 in numbers which are found insufficient. People who collect water from standpipe, have to wait in long queue but most of the times they fail to collect the required amount of water. In case of water collection distance, $11.5 \%$ people were identified who have to travel $40 \mathrm{~m}$ or more to collect drinking. Water the study reveals that another 900 standpipe connections (10 in each ward x 90 wards) are needed for the under privileged people. During field survey, the microbiology and chemical report of DWASA's supplied water indicated that, different parameters of groundwater supplied by DWASA are under permissible limit, but the water gets contaminated during distribution through pipe joints at different places.

\section{System loss or unaccounted water}

System loss comprises of wastage and illegal connections for which the supply cannot attain the 100 percent. People collect water from the mainline without permission or in contract with the corrupted person of the supply authority. During the financial year 2002-2003, almost 52\% system loss was accounted that indicates very poor management scenario (Fig. 2). The situation has been fluctuating but never come to an admissible limit. With this and by the increasing effort of the DWASA officials, the system loss is gradually decreasing.

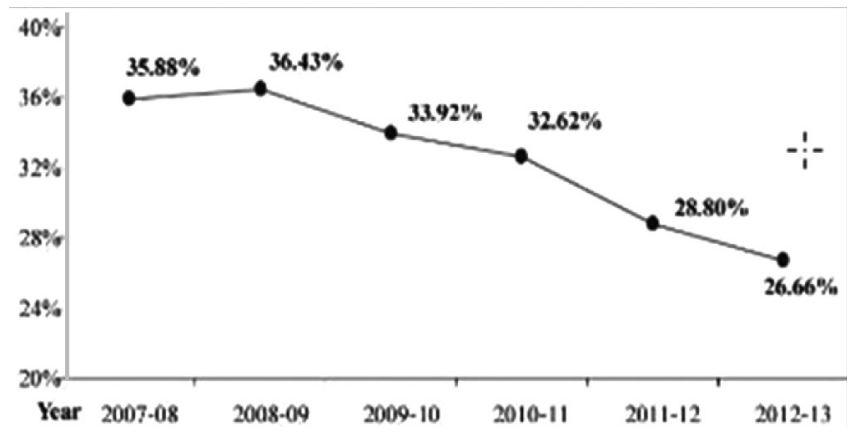

Fig. 2 : System loss in different financial years (DWASA 2014).

\section{Assessment of water quality served by DWASA}

DWASA relies on both ground and surface water for maintaining water supply in Dhaka city. DWASA complains that, approximately one thousand and five hundred of road side dustbins are not cleaned by DCC since a long time and thus caused hindrance to the sewerage system of DWASA and thus deteriorated the quality of supply water. Groundwater quality is generally examined during the installation of a new 
pump but, on a monthly basis DWASA is tasked to check. DWASA claims that supplied groundwater is pure and does not contain heavy metal. But, due to illegal and unnoticed connection leakage, water logging, free disposal of urban/ chemical and putting sewerage line together with water supply pipes etc. contamination process takes place and these cannot be overcome only by DWASA. Moreover, the good quality of water becomes undrinkable once enter into reserve tank installed in the house. The quality of water deteriorates for long time storing and for keeping in unclean overhead tanks. It was found that the bacteriological quality of WASA source water at the point of pump station was superior than that of pipeline or house tap water point. Contamination of water take place in distribution system and/or domestic tanks or reservoirs.

Table 2: Quality of water supplied by DWASA (DWASA 2014).

\begin{tabular}{|lccc|}
\hline Parameters & $\begin{array}{c}\text { Standard quality prescribed } \\
\text { by WHO }\end{array}$ & $\begin{array}{c}\text { Deep Tube Well } \\
\text { Water Reservoir at } \\
\text { consumer level }\end{array}$ \\
\hline Color (Pt./Co. Unit) & 15 & 4 & 20 \\
Turbidity (N.T.U) & $5-10$ & 1.17 & 8.28 \\
$\mathbf{p}^{\mathbf{H}}$ & $6.5-8.5$ & 6.7 & 7.06 \\
TDS (mg/L) & 1000 & 117 & 231 \\
Conductivity ( $\boldsymbol{\mu S} / \mathbf{c m})$ & $-1.5-1.5$ & 233 & 461 \\
Ammonia-N (mg/L) & 0.5 & 0.001 & 7.615 \\
\hline
\end{tabular}

Consumers alleged that the supply water smells bad due to excessive chlorination and presence of ammonia. Even though presence of heavy metal in supplied water of DWASA is still under admissible limit. The National Drinking Water Quality Survey 2009 showed that, about 40 percent drinking water contains more than one milligram of iron per liter and 35 percent contain 0.4 milligrams manganese per liter which may affect both the human taste and health (BBS, MICS and UNICEF 2011).

\section{Future water demand and supply in Dhaka city}

At present DWASA has the sole responsibility of ensuring water supply and sewerage services to Dhaka city dwellers. It is hardly possible for DWASW to meet up the demand of the increasing trend of population. So, along with DWASA, DPHE and other NGOs should come forward to work more actively to reduce extra pressure from DWASA. The gap is wide in consumption pattern as from about 20 liters per capitaday in low income slums to about 400 liters per capita-day are provided in high income areas. Table 3 indicates the water production road map to meet the future demand of Dhaka city by DWASA.

Table 3: Water Production Road Map to Meet Future Demand (Uddin 2011).

\begin{tabular}{|l|l|l|l|}
\hline \multicolumn{1}{|c|}{ Demands } & \multicolumn{3}{c|}{ Year } \\
\hline Total water requirement & 2015 & 2020 & 2025 \\
\hline Total user-end demand & 2474 & 2769 & 3064 \\
\hline UFW (\%) & $30 \%$ & $30 \%$ & $30 \%$ \\
\hline GW (MLD) & 2088 & 2088 & 2088 \\
\hline Sayedabad SWTP I (MLD) & 225 & 225 & 225 \\
\hline Sayedabad SWTP II (MLD) & 225 & 225 & 225 \\
\hline SWTP III (Khilkhet) (MLD) & 500 & 500 & 500 \\
\hline SWTP IV (Padma) (MLD) & & 500 & 500 \\
\hline SWTP V (Sayedabad) MLD & & & 500 \\
\hline Total production capacity (MLD) & 3038 & 3538 & 4038 \\
\hline $\begin{array}{l}\text { Total user-end gap (30\% UFW) } \\
\text { (Total user-end gap- 30\% UFW- } \\
\text { Total user-end demand) }\end{array}$ & -387.4 & -292.4 & -237.4 \\
\hline
\end{tabular}

\section{CHALLENGES TO ACCESS IN DRINKING WATER}

Drinking water availability consists of the major issues like quantity and quality of potable water, contamination of surface water, flooding and drainage congestion, water logging, ground water depletion and deterioration of water quality of the peripheral river system etc. The improvement of water management and services remains as a key challenge towards ensuring sustainable governance system. The treatment of this water has become so expensive that water supply agencies are almost entirely dependent on ground water aquifer for their potential alternative source of water supply. On the other hand, accesses to supplied water by DWASA are not same in all the areas of DWASA. Rather it varies from areas to areas with the changing socio-economic status. Water borne diseases are the major cause of morbidity and mortality in developing countries like Bangladesh. Water contamination creates serious health hazard for Bangladesh. As such, an Integrated Water Resource Management (IWRM) body is required to face all the challenges for smooth supplying of drinking water.

\section{CRISIS MANAGEMENT OF DRINKING WATER}

Drinking water crisis management is one of the most critical challenges in Dhaka city. It is urgent to increase the use of surface water by reducing the dependence on aquifer as to mitigate the shortage of drinking water (The Daily Star, March 22, 2013). This problem is not a new one and it cannot be solved overnight. Thus, there is no other alternative but to undertake the Integrated Water Resources Management (IWRM) to save the city from social, economical and environmental disaster. Simultaneously, change in water consumption behaviour, modification of pricing, taxing, reduction of system loss, development of human resource, institutional reform and sustainable planning, considering impacts of climate change, should be brought under common goal to get the best outcomes. Accordingly, the government should take steps for specific planning and allocation of water resources for people living in different zones around the city. 
In order to manage this complicated situation it has become necessary to integrate few major issues, these are: socioeconomical issues, institutional issues, water quality issues, rain water harvesting, effective pricing of water, community deep tube wells, flood water management and use of water way communication to avoid water crisis in Dhaka.

\section{FINDINGS}

DWASA provides water in the developed areas and DPHE in the under privileged and rural areas in Dhaka City. During field survey it was found that $80 \%$ of the city dwellers depend on DWASA and $45 \%$ of the dwellers of southeast of Dhaka complained that they found bad smell in supplied water of DWASA. At present the actual system loss of DWASA is about $35.5 \%$ of which $14 \%$ is administrative loss, 11 percent is technical loss and remaining $10.5 \%$ occurs due to illegal connections. Regular extraction of water from deep aquifers has caused declination of water level by 2 to $3 \mathrm{~m} / \mathrm{yr}$ depending on the location which may lead to a serious environmental challenge in Dhaka city. Groundwater recharge for Dhaka city is $1.33 \mathrm{~m} / \mathrm{yr}$ while the groundwater depletion rate is $2.81 \mathrm{~m} / \mathrm{yr}$. As such, most of the tube wells are not functioning properly within short time of installation and inhabitants are facing acute crisis to procure drinking water. Factorslike inadequate drainage system, waste disposal of tanneries, factories/ industries, flood water etc. are found as major factors of water contaminations. The slum dwellers and inhabitants of low lying areas people are most deprived of pure drinking water especially during flood or any disastrous situation. People in the flood affected areas suffered from a variety of diseases, e.g. skin diseases due to exposure of polluted flood water, and diarrhea and other water borne diseases by drinking contaminated water. More number of overhead tank should be established in zone wise to avoid water crisis. The existing and future crisis of drinking water around Dhaka city can be managed by DWASA/DPHE through laying down bigger diameter pipe lines by DWASA, taking initiatives by DPHE to establish community based deep tube wells at least one in each ward of Dhaka. DWASA should be divided into two regions i.e. north and south to properly administer the organization. More number of water treatment plants may be installed in zone wise. Local government organizations, DPHE and Dhaka City Corporation should jointly make efforts to keep the surface water body as much as clean. The government should supervise regularly the drinking water producing factory on their quality check as well as should take proper initiatives to ensure and manage potable drinking water.

\section{CONCLUSIONS}

Overcoming water shortage will be a key issue for sustainable development. The enormous number of inhabitants of Dhaka city are experiencing acute shortage of water and facing crisis of pure drinking water round the year. The water supply coverage areas of DWASA are divided in to seven zones.
But, people living in the backward and low-lying areas of the city are still deprived of water supply of DWASA but getting the deep tube well and well coverage of DPHE. Due to various reasons, the city dwellers do not accept the water of DWASA as drinking water. They boil and filter the water for drinking purpose. People are becoming habituated to have the water from sealed bottle for their safety. DWASA is putting more emphasis on the use of surface water since the ground water level of Dhaka is decreasing gradually. DWASA has planned to build four large surface water plants by the year 2021 at the cost of US\$1.8 billion. In order to make the water supply system sustainable, water tariff should be determined on the basis of the cost of water production, operation, maintenance, depreciation values and administration full Treated grey water can play a major role in substituting and supplementing DWASA's water supply. The government. should assign priority for supplying water to under-served and un-served areas of greater Dhaka city. Regular monitoring on qualitative, quantitative issues and evaluation for drinking water is very essential. Necessary measures to be adopted for preventing contamination of ground and surface water by managing solid and liquid wastes, ensuring growing water demand and to reduce dependency on ground water for maintaining sustainable health, environment and development for the Dhaka city dwellers.

\section{RECOMMENDATIONS}

To make better condition of drinking water supply, the followings are recommended.

- An IWRM and its distribution system may be re-organised to meet the water requirement for Dhaka City dwellers.

- The service of DWASA should be divided into two regions i.e. north and south and should expand their working areas to ensure equal and adequate supply of drinking water.

- To achieve the sustainability in drinking water within golden jubilee of our independence (2021), the present water production capacity of 2481.72 MLD (DWASA 2014), may be gradually increased to $3,038.72$ MLD by the year 2015, 2,896.72 MLD by the year 2018, 3538.72 MLD by the year 2020. The DWASA should produce a total of 4,038 MLD by the year 2025 .

- $\quad$ Existing water supply of DWASA should be modernized and more number of water treatment plants and overhead tanks in zone wise may be established.

- High capacity water pumps may be installed gradually to replace the old ones to increase the wide coverage. More number of overhead and service tanks may be established according to the number of population in the zones. DWASA may ensure regular maintenance, cleaning of the tanks, check the proper and legal connection of water supply line, minimise loss and wastage of water, introduce prepaid billing system to revenue loss, and also should take necessary steps to raise mass awareness through print and electronic media to aware people regarding "right to water" and to ensure effective participation to protect water from wastage. 
- Low-cost effluent treatment process and efficient solid waste management may be introduced to lessen water contamination and solid waste is to be certainly processed to valuable products.

- The city dwellers may be encouraged to preserve rain water for their daily use.

- Private and international investment efforts may be welcomed and regulated in such a way that it could enhance the capacity building of government institutions in order to get drinking water at an affordable cost.

- All existing drinking water production business organizations may be shifted near the river bank.

- All chemical industries and industries consuming water for production may be forced to shift outskirt of Dhaka.

- The government may take necessary steps to re excavate water catchment areas to preserve surface water and protection of wetlands.

- Introducing water way communication inside and outside of Dhaka city to maintain surface water reservoirs which ultimately contribute to the regular recharge of groundwater.

- Regular research and development activities may be carried out by DWASA and DPHE to improve the quality of drinking water.

\section{REFERENCES}

Akther, H, Ahmed, M. S. and Rasheed, K. B. S., 2009, Spatial and temporal analysis of groundwater level fluctuation in Dhaka City, Bangladesh. Asian Jour. Earth Sci., v. 2, pp. 49-57.

BBS, MICS and UNICEF, 2011, Bangladesh national drinking water quality survey of 2009. Retrieved from http:// www.unicef.org/bangladesh.

Gomes, D. J., 2005, Waterborne illness: A real disaster in Bangladesh. Proc, Japan-Bangladesh Joint International Conference on Microbiology Education \& the Prospect of Japanese Collaboration in Education and Research.

DWASA (2014). Annual Report 2013-2014. Dhaka Water Supply and Sewerage Authority, Ed. Zakaria AI Mahmud, $131 \mathrm{p}$.

Khan, A. T., 2011, Dhaka Water Supply and Sewerage Authority: Performance and Challenges.

Rahman, A. A. and Alam, M., 2005, Dhaka City: State of Environment (SOE), UNEP, Dhaka. Retrieved from www.rrcap.unep.org/pub/soe/Dhaka.

Uddin, A. and Baten, A. M., 2011, Water supply of Dhaka City: Murky Future, The Issue of Access and Inequality.

WHO/UNICEF, 2010, Joint monitoring program for water supply and sanitation 2003-2010. Retrieved from www. wsinfo.org/data-estimates/table. 